\begin{tabular}{c}
\hline \hline Review \\
\hline \hline $\begin{array}{l}\text { Juntendo Medical Journal } \\
\text { 2010. 56 (1), P. 37 44 }\end{array}$
\end{tabular}

\title{
Reactive Oxygen Species, Nitric Oxide and the Kidney
}

\author{
Mochammad THAHA*1)3) Emilia S TAnUSEPUTRA*2) Yasuhiko TOMino*1)3)
}

\begin{abstract}
Nitric oxide (NO) is a potent, endogenous vasodilator that regulates various functions including systemic blood pressure and renal function, among other functions. The bioactivity of NO is reduced by superoxide, a major reactive oxygen species. Overproduction of superoxide and other related reactive oxygen species resulting in oxidative stress reduces the biological effects of NO. Although both of these highly reactive species play distinct roles in other pathways, their interaction is emerging as a major regulatory factor in normal and pathological renal function. Endothelial nitric oxide synthase (eNOS) is one of three isoforms of NOS that exhibits homology of sequence and function and plays a crucial role in regulating a wide spectrum of the cardiovascular (CV) system. Biochemically, endothelial NO production is regulated at three different levels, namely eNOS gene expression, eNOS enzymatic activity and degradation of NO. Dysfunction of any of these mechanisms can cause endothelial dysfunction.

In this review, recent studies on NO in the kidney are highlighted, focusing on the interactions of these mechanisms under normal and pathological conditions as well as examining Glu298Asp polymorphism in end stage kidney disease (ESKD) patients in the dialysis unit of the Internal Medicine Department, Medical Faculty Airlangga University, Surabaya, Indonesia.

Key words : Nitric oxide (NO), Reactive oxygen species, eNOS gene polymorphism, Kidney
\end{abstract}

\section{Introduction}

Reactive oxygen species (ROS) are metabolites of oxygen that can either strip electrons away from other molecules (oxidize), donate electrons to molecules (reduce), or react with and become part of molecules (i. e. oxidative modification). Another relevant group of molecules are the reactive nitrogen species (RNS) including nitric oxide (NO), the nitrogen dioxide radical $\left(\mathrm{NO}_{2}\right)$, and the nitrosonium cation $\left(\mathrm{NO}^{+}\right)^{1)}$

NO produced by vascular endothelial cells is a gaseous free radical with only a few seconds of biological half-life, which has been identified as playing critical roles in a remarkable array of essential biological processes, ranging from neurotransmission, control of vascular tone and blood pressure, thrombotic properties, kidney functions including fluid homeostasis, apoptosis and inflammation ${ }^{2}$. Under normal circumstances, the kidney generates reactive oxygen species (ROS), including superoxide anions $\left(\mathrm{O}_{2}{ }^{-}\right)$, hydrogen peroxide $\left(\mathrm{H}_{2} \mathrm{O}_{2}\right)$, peroxynitrite $\left(\mathrm{ONOO}^{-}\right)$and hydroxyl radical $\left(\mathrm{OH}^{-}\right)$, which are efficiently eliminated by enzymatic-superoxide dismutase (SOD), catalase, glutathione peroxidase (GPX) and non-enzymatic (glutathione, vitamins $\mathrm{C}$ and $\mathrm{E}$ ) systems. Overproduction of superoxide and other related reactive oxygen species resulting in oxidative stress reduces the biological effects of NO. Superoxide generates much of its biological effects by scavenging NO produced by three isoforms of nitric oxide synthase (NOS), each expressed in the kidney, neuronal or type 1 (nNOS) ; inducible or type II (iNOS) and endothe-

* 1) Internal Medicine Department, Medical Faculty Airlangga University Surabaya, Indonesia

* 2) Royal Medical and Dental Clinic Surabaya, Indonesia

* 3) Department of Internal Medicine, Division of Nephrology, Juntendo University Faculty of Medicine, Tokyo, Japan

〔Received Oct. 21, 2009〕〔Accepted Nov. 21, 2009〕 
lial or type III ${ }^{3)}$.

The purpose of this review is to highlight the recent studies on NO in the kidney, focusing on their interaction in normal and pathological conditions and also Glu298Asp polymorphism in end stage kidney disease (ESKD) patients in our dialysis unit.

\section{Pathology of NO}

\section{I . Renal distribution of NOS}

Over the last two decades, it has become evident that decreased bioavailability of endothelial NO produced from endothelial NO synthase (eNOS), referred to as endothelial dysfunction, plays a crucial role in the development and progression of atherosclerosis. Much progress has been made in understanding the mechanism of decreased endothelial NO bioavailability at the levels of regulation of eNOS gene expression, eNOS enzymatic activity and NO inactivation ${ }^{4}$. Intrarenal localization of the major NOS isoforms has been explored in detail with immunohistochemistry, in situ hybridization, and renal microdissection combined with RT-PCR. nNOS has been detected in the macula densa segment in the endothelium of the efferent (but not afferent) arterioles, glomerular visceral epithelium, nerves neighboring the arcuate and interlobular arteriesfpelvic epithelium and in a subset of medullary thick ascending limb cells (mTAL) (Figure-1) ${ }^{5}$. Endothelial NOS (eNOS) have been detected in several cortical and medullary structures primarily in the endothelium of the glomerular capillaries, afferent and efferent arterioles, intrarenal arteries, and medullary vasa recta (Figure-1 and 2) ${ }^{5}$. iNOS expression has been demonstrated on immunoblots of renal outer and inner medullary proteins. Tissue culture studies have also provided evidence for the presence of iNOS mRNA and inducible NO production in cytokine or cAMP-stimulated glomerular mesangial cells, lipopoly saccharide (LPS) and/or cytokinestimulated proximal tubule cells, inner medullary collecting duct cells and mTAL cells ${ }^{6}$.

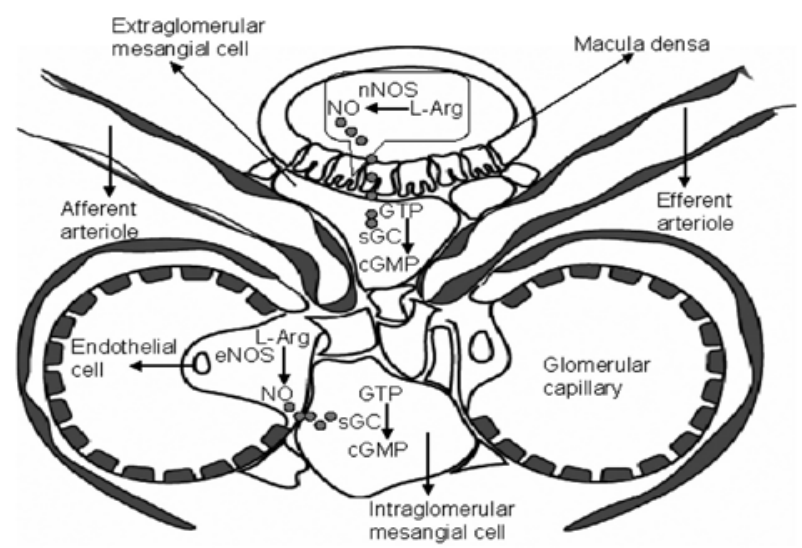

Figure-1 Distribution of NO-cGMP signaling in the glomeruli (Bachmann S, et al : Am J Physiol, $1995 ; 268$ : F885 898).

L-Arginine (L-Arg), NO (nitric oxide), Endothelial NO synthase (eNOS), neuronal NOS

(nNOS), cGMP (cyclic guanosine monophosphate), GTP (guanosine 5`-triphosphate), sGC (soluble guanylate cyclase).

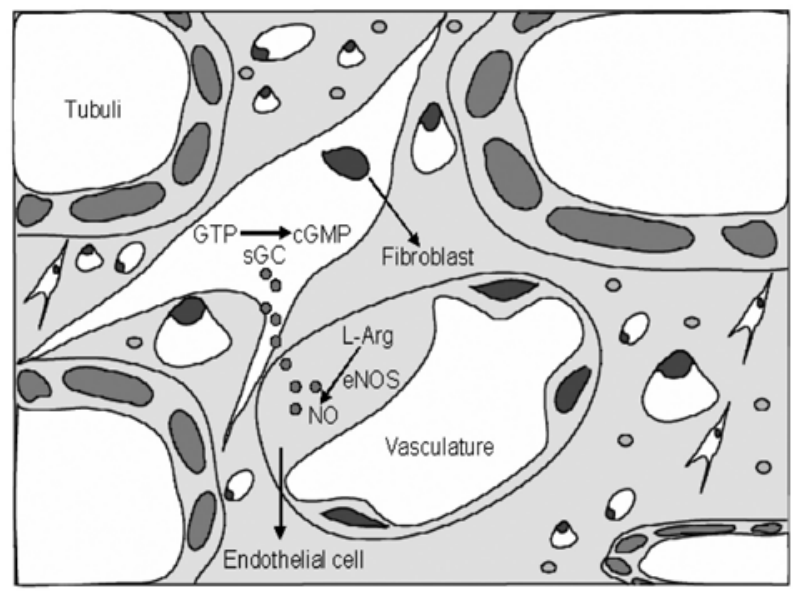

Figure-2 Distribution of NO-cGMP signaling in the tubulointerstitium (same as Fig.1).

$\mathrm{L}$-Arginine (L-Arg), NO (Nitric oxide), endothelial NO synthase (eNOS), neuronal NOS

(nNOS), cGMP (cyclic guanosine monophosphate), GTP (guanosine 5-triphosphate), sGC

(soluble guanylate cyclase).

\section{II . Renal physiology of NO}

Several new studies indicate that production of both superoxide and $\mathrm{NO}$ are involved in normal kidney and vascular function. Both may act as intermediate signaling processes involved in maintaining vascular tone and tubular function.

1) Renal microcirculation

NO plays a major role in maintenance of renal perfusion and glomerular filtration in the normal kidney. In several species, including humans, acute 
systemic NO synthesis inhibition with L-arginine analogs produces dose-dependent increases in arterial blood pressure (BP) and renal vascular resistance (RVR) that are reversible with excess $\mathrm{L}^{-}$ arginine ${ }^{7)}$. When BP increases, some of the increase in RVR is autoregulatory ; however, intrarenal local and low-dose systemic NOS inhibition produces renal vasoconstriction in the absence of increased BP. Thus, NO generated within the kidney lowers RVR. The increases in RVR due to NO synthesis inhibition causes reduction in renal plasma flow (RPF) and glomerular filtration rate (GFR), although GFR decreases proportionately less than $\mathrm{RPF}$ because the filtration fraction rises ${ }^{7)}{ }^{8}$. The relationship between tonically produced NO and the vasoconstrictor systems including angiotensin II (AII), sympathetic nerve system (SNS) and endothelin (ET) is very complex and highly variable. In anesthetized surgically stressed animals, all of the above vasoconstrictor systems are apparently active tonically in the renal vasculature. NO attenuates their various vasoconstrictor actions within the renal microcirculation ${ }^{9)}$. When the renin-angiotensin system is acutely activated by volume depletion, surgical stress, etc. or when exogenous AII levels are raised by infusion, the renal vasoconstrictor response to acute NOS inhibition is partly due to $\mathrm{AII}^{10)}$. During blockade of the renin-angiotensin system, the renal vasoconstrictor responses to NOS inhibition were blunted. These findings suggested that local AII and NO exert a modulatory influence on the renal microvasculature ${ }^{10)}$.

Patzak et al. ${ }^{11)}$ perfused isolated mouse afferent arterioles. They showed that intraluminal perfusion of Ang II decreased diameter dose-dependently and simultaneously enhanced NOS expression. These effects were not altered by inhibition or stimulation of $\mathrm{AT}_{2}$ receptors. These results show that Ang II, acting via $\mathrm{AT}_{1} \mathrm{R}$ and not $\mathrm{AT}_{2} \mathrm{R}$, induces NO in the afferent arterioles, which acts to buffer its constrictor action. This relationship between Ang II and NO may be missing in chronic treatment. In mice, excretion of NO metabolites was decreased after 28 days of Ang II infusion, consistent with reduced endothelial NOS expression in the renal cortex ${ }^{12)}$. Since neuronal NOS is specifically involved in the control of cortical blood flow, its effect should have been evaluated. Expres- sion of the components of the nicotinamide adenine dinucleotide phosphate-reduced form (NADPH) oxidase in the renal cortex was decreased by A II (Figure-3). The responsiveness of the rat afferent arteriole to Ang II was determined by intracellular calcium levels, measured by fluorescence in isolated vessels. Angiotensin II increased intracellular calcium levels and superoxide, and both were suppressed by the antioxidants, apocyanin and tem$\mathrm{pol}^{13)}$. This study showed that Ang II rapidly alters afferent arteriole resistance via formation of superoxide.

\section{2) Tubular function}

Nitric oxide generated by neuronal NOS in the macula densa modulates afferent arteriole tone via tubuloglomerular feedback (TGF). Neuronal NOS is activated by increased flow to the macula densa, but changes in intracellular $\mathrm{pH}$ may also be important. Using $\mathrm{NO}$ and $\mathrm{pH}$ sensitive dyes in an in-vitro preparation of the afferent arterioles and attached thick ascending limbs of Henle (TALH), intracellular $\mathrm{pH}$ and $\mathrm{NO}$ in the macula densa increased with high salt perfusate, a stimulus for $\mathrm{TGF}^{14)}$. Blocking sodium/hydrogen exchange prevented the increase in intracellular $\mathrm{pH}$ and blunted $\mathrm{NO}$ in the macula densa during high salt perfusion. Selective blockade of neuronal NOS by 7-nitroindazole also reduced NO in the macula densa during high salt perfusion, suggesting the results were not due to $\mathrm{pH}$ effects on the dyes. This study showed that $\mathrm{pH}$ changes in the macula densa activate neuronal NOS during TGF and contribute to

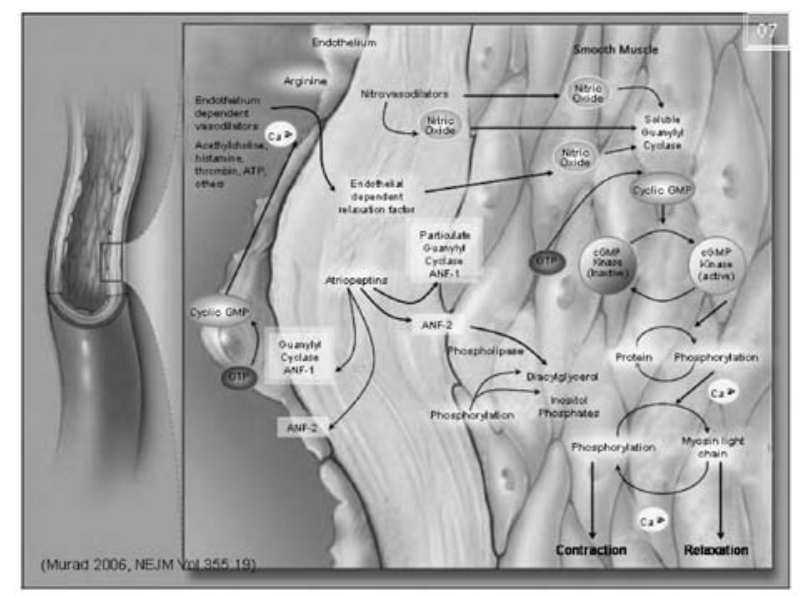

Figure-3 Potential action of nitric oxide in vascular walls (Murad F : N Engl J Med, 2006 ; 355 : 2003 2011.). 
regulation of afferent arteriole tone. Superoxide enhances sodium and water reabsorption and is implicated in salt-sensitive hypertension. To examine a possible mechanism of this action, Juncos and Garvin ${ }^{15)}$ perfused isolated TALH and measured intracellular concentrations of sodium and chloride by fluorescent markers. Generation of superoxide by the combined hypoxanthine and xanthine oxidase increased intracellular sodium $\left(\begin{array}{lll}571 & \%\end{array}\right)$ and chloride $(528 \%)$. The rate of uptake was similar for both sodium and chloride with and without oxidative stress, indicating that the sodium, potassium, 2-chloride cotransporter (NKCC) was activated by superoxide. The activity of sodium/ potassium ATPase was not changed by hypoxanthine/xanthine oxidase. The effect of inhibitors of NKCC was not tested in this study, which may be needed to clarify the role of this transporter. High salt intake increases neuronal NOS expression in the TALH, and the resultant NO may contribute to normal adaptive response to increase excretion. Herrera and Garvin ${ }^{16)}$ using tissue preparations from TALH showed that the increased neuronal NOS is linked to high osmolality associated with high salt intake, which stimulates endothelin (ET) 1. Bosentan, an ETB receptor antagonist blocked the high salt stimulated neuronal NOS expression.

Morishita et $a l^{17)}$. engineered and characterized triple (endothelial, neuronal and inducible NOS) NOS knockout mice to identify more specific roles for NO. In their first report of this model, they show that these mice developed normally, but showed greater mortality. They also had hypotonic polyuria, and polydipsia that was not affected by vasopressin, indicating a form of nephrogenic diabetes insipidus. Aquaporin 2 expression in the collecting duct was reduced in the triple knockout, which may explain these results. The authors offered no mechanism, however, for the interaction of aquaporin and NOS. Therefore, all the above data suggest that basal NO synthesis plays an important role in the renal regulation of the extracellular fluid volume and blood pressure, and that inhibition of NO synthesis reduces the adaptive increase in urinary sodium excretion and further prolongs the increases in the extracellular fluid volume.

3) Ischemia/reperfusion injury and acute renal failure
New evidence suggests that oxidative stress has a crucial role in the pathogenesis of ischemia/reperfusion injury and acute rejection of renal al$\operatorname{lografts}^{18)}$. In acute renal failure, the roles of NO are ambiguous and are still incompletely understood. In vitro studies shown that NO can improve renal tubular epithelial and vascular endothelial regeneration after injury due to postischemic acute renal failure. In contrast, the nonselective NOS inhibitors protect renal cortical tubules against hypoxic injury, and selective inhibition of iNOS with antisense oligodeoxynucleotides protected renal epithelial cells from oxidative cellular injury suggesting NO-mediated cytotoxicity in some settings ${ }^{19)}$. In “in-vivo" studies, nonselective NOS blockade exacerbated mTAL injury in renal failure induced by radiocontrast agents. In contrast, systemic administration of NOS are different phases of the disease for NO production. Reduced endothelium derived NO production causes vasoconstriction and worsens ischemia. Increased NO production from iNOS exacerbates the injurious effect of ischemia on these cells, so that any therapeutic intervention designed to modulate NO in acute renal failure requires selective alterations of NO production within the endothelium (eNOS) and/or renal tubular cells (iNOS) ${ }^{20)}$. NADPH oxidase and especially xanthine oxidoreducttase activities were increased in experimental renal allografts, associated with increased ROS generation and signs of acute rejection ${ }^{21)}$. Inhibition of xanthine oxidoreductase with tungsten markedly suppressed ROS production, inflammation and rejection signs, suggesting that it is the main source of ROS after transplantation. The ROS scavenger edaravone also improved renal function and decreased renal tubular damage and mortality. Several agents with antioxidant properties have been shown to be renoprotective in animal models of ischemia/reperfusion and nephrotoxicity ${ }^{22)}$ not only decreasing ROS but also restoring the antioxidant enzymes. Enhancing NO ameliorates ischemia/reperfusion, possibly by suppressing ET-1, a powerful vasoconstrictor acting via $\mathrm{ETB}^{23)}$. Ischemic preconditioning reduces ischemia/ reperfusion injury and NOS may be implicated. Ischemic preconditioning is induced by short periods of ischemia/reperfusion and promotes activation of substances and intrac- 
ellular signaling cascades that protect cells against both necrosis and apoptosis during a subsequent more prolonged ischemia/reperfusion. The severity of ARF was reduced by ischemic preconditioning in endothelial NOS $(P / D)$ mice, but not in mice pretreated with nitro-L-arginine, a non-selective NOS inhibitor. The inducible NOS inhibitor aminoguanadine had no effect ${ }^{24}$. The role of endothelial NOS was confirmed by the absence of any improvement of ARF by ischemic preconditioning in endothelial NOS (-/-) mice, supporting the protective role of nitric oxide in ischemia/reperfusion ARF. These studies confirm that oxidative stress contributes to ischemia/reperfusion injury and ARF mediated by its effects on nitric oxide. Strategies that reduce oxidative stress or promote NOS activity should provide beneficial therapy.

\section{Gene Polymorphism of NO}

In genetic studies, gene polymorphism of the nitric oxide synthase (NOS) has been found to be related to the pathogenesis of certain diseases ${ }^{25}$. Wang reported evidence of an association between higher susceptibility to coronary lesions and a particular polymorphic type of eNOS locus in cigarette smokers ${ }^{26)}$. Miyahara et al. ${ }^{27)}$ reported cloning and structural characterization of the human eNOS gene and suggested that a five tandem repeat in a $27 \mathrm{bp}$ consensus sequence in intron 4 might serve as a genetic marker. Recently, a polymorphism of the human eNOS gene appeared to be linked to hypertension and chronic kidney disease (CKD) in Japanese has been identified. However, whether or not changes in eNOS expression and/or function occur as a result of such polymorphisms remains controversial and needs further study.

1) eNOS gene polymorphism in ESKD patients

Significant 298Asp mutation has recently been reported in coronary artery disease, acute myocardial infarction ${ }^{28)}$, essential hypertension, carotid atherosclerosis and preeclampsia. Specifically, Glu298Asp mutations at the exon 7 polymorphism of the eNOS gene were evaluated in the majority of these studies. Although a significant association was described in some studies, other studies reported no such association with progression of nephropathy in Type $2 \mathrm{DM}$. Thaha et al. reported the frequency of Glu298Asp in 100 ESKD patients and 100 healthy controls (Figure -4$)$. The distribution of genotypes in the healthy controls did not differ significantly from that expected under the Hardy Weinberg equilibrium model. In the ESKD patients, the positivity of Glu298Asp was significantly higher than that in healthy controls $\mathrm{p}<$ 0.0001). The odds ratio (OR) for the ESKD patients was OR 4.57 (CI $95 \%: 2.52-8.31$ ). There were statistically significant differences between the two groups with respect to age $(46.62 \pm$ 11.89years in the ESKD patients versus38.69 \pm 10.50 years in the healthy controls, mean $\pm \mathrm{SD}, \mathrm{p}<$ 0.0001 ) and gender (male to female ratio, $62: 38$ in ESRD patients versus $34: 66$ in healthy controls, $\mathrm{p}<0.0001)$. The ESRD group did not show any difference in age between genotypes: GG genotype $(45.11 \pm 12.58$ years $)$, GT genotype $(47.40 \pm$ 11.65years) and TT genotype (48.66 \pm 9.45 years, $\mathrm{p}=0.6324)^{29)}($ Figure -5$)$.

2) Association between ESKD associated with type 2 diabetes (DM) and polymorphism of

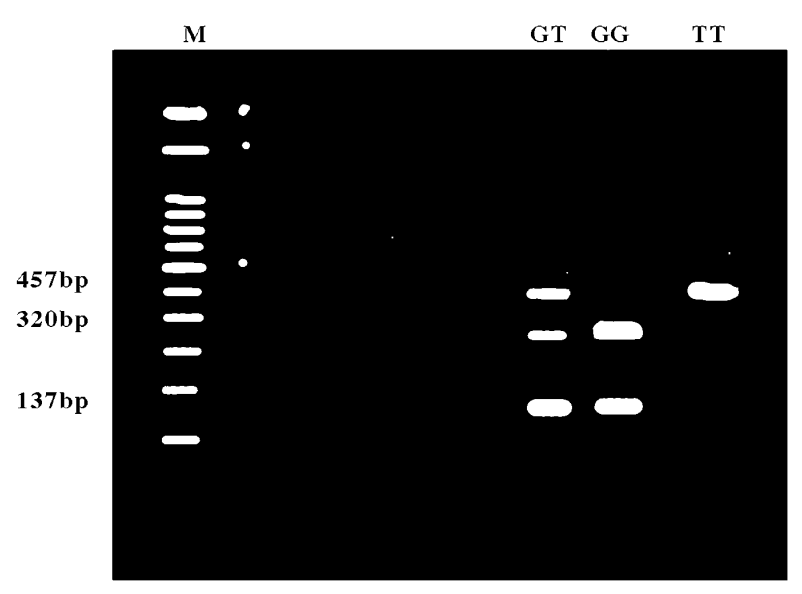

Figure-4 PCR Results on representative agarose gel 2\% Representative agarose $2 \%$ gel stained with ethidium bromide and photo graphed under UV transillumination ${ }^{29)}$

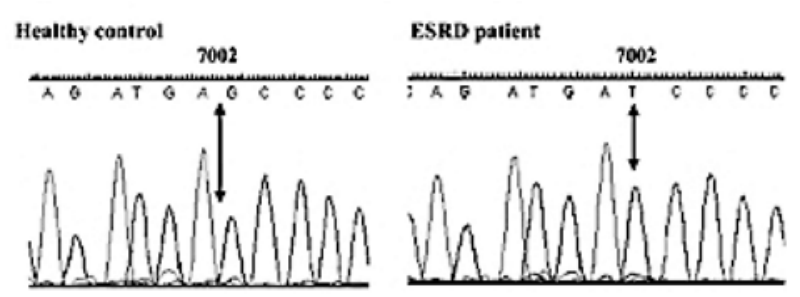

Figure-5 DNA sequencing

The eNOS exon 7 was amplified from genomic DNA of healthy control subjects (left) and patients with ESKD (right) and sequenced directly, revealing a homozygous $\mathrm{G}$ to $\mathrm{T}$ transition at nucleotide position $7002^{29}$ 
the eNOS gene

In the ESKD patients, 39 patients had type 2 diabetic nephropathy. The positivity of 298Asp in this subgroup was signifcantly higher than that in healthy controls $(\mathrm{p}<0.0001)$, OR was $8.64(95 \%$ CI : 2.51-29.72) in the male ESRD patients, and 18.67 (95\% CI : 3.85-90.40) in the female ESKD patients. The allelic frequency of 298Asp in type 2 DM subgroup was 33 (42.3\%), which was higher than $30(15 \%)$ in the healthy controls (Thaha et $a{ }^{29)}$ ). Glu298Asp polymorphism in ESKD and association with type $2 \mathrm{DM}$ patients were observed for the first time in Indonesia, demonstrating a significant increase of 298Asp in ESKD patients. It also revealed a significant presence of this mutation predominantly in patients with ESKD resulting from type $2 \mathrm{DM}$. The allelic frequencies of 298Asp for Glu298 in DM-derived ESKD patients were also significantly higher than those in the healthy controls. These genetic defects pointed to 298Asp not only as the candidate gene of progressive renal diseases, but also as a possible prognostic factor in patients with DM-derived ESKD ${ }^{29)}$.

3) Association between ESKD associated with hypertension (HT) and polymorphism of the eNOS gene

In the ESKD group, 44 patients had ESKD resulting from HT. The frequency of Glu298Asp in this subgroup was compared with that in healthy controls. In patients with the HT-derived ESKD subgroup, the positivity of 298Asp was significantly higher (males $\mathrm{p}<0.036$, females $\mathrm{p}<0.005$ ) than that in healthy controls. The allelic frequency of 298Asp in the HT subgroup was 27 (30.7), which was also higher than $30(15 \%)$ in the healthy control group ${ }^{29}$. Genetic association studies that examined whether polymorphisms in the eNOS gene are associated with HT have provided controversial and inconclusive results but as has been reported by Miyamoto et al. ${ }^{30)}$ revealed a strong association of Glu298Asp with HT. This study examined the association of Glu298Asp with HT. The frequency of Glu298Asp in the HT subgroup was compared with that of healthy controls. In the patients in the HT-derived ESKD subgroup, the positivity of 298 Asp was significantly higher. The allelic frequencies of 298Asp for Glu298 in hypertensive patients were higher than those in the healthy controls. Thaha et al. ${ }^{29)}$ conducted an updated meta-analysis of studies by Noiri et al. ${ }^{31)}$. They and our study as genetic association studies evaluating the role of Glu298Asp in ESKD patients. This meta-analysis showed that 298Asp frequencies are more predominant in the ESKD group than in the control group ( $p$ value $<0.005$ ). They also compared the study by Noiri et al. ${ }^{31}$, which analyzed the 298Asp frequencies based on age and gender. In the group $<50$ years, both our study and the Noiri study showed that 298Asp is more prevalent in ESRD that in the control $(\mathrm{p}<0.0001)$ and $\mathrm{OR}$ was 4.50 (95\% CI : 2.45-8.28). In contrast, in the group $>50 y e a r s$, these studies showed a contradiction $(\mathrm{p}=0.197)$. Furthermore, in females both studies showed that 298Asp was predominant in the ESKD group compared with controls ( $\mathrm{p}$ value $<0.005$ ) (OR 4.38, 95\% CI : 1.63-11.80) whereas in males the result was contradictory $(\mathrm{p}=0.135)$.

\section{Conclusion}

The bioactivity of nitric oxide (NO) is reduced by superoxide, a major reactive oxygen species (ROS). Overproduction of superoxide and other related reactive oxygen species resulting in oxidative stress reduces the biological effects of nitric oxide. Although both of these highly reactive species have distinct roles in other pathways, their interaction is emerging as a major regulatory factor in normal and pathological renal function. The role of genetic polymorphism of NOS enzymes and decreased arginine in the kidney as a contributor to NO deficiency is appealing in advanced diabetic nephropathy and hypertension. It appears that Glu298Asp is a predisposing factor in ESKD, especially DM-derived and HT-derived ESKD. The observed accumulation of 298Asp, especially in patients with DM as a cause of ESKD, suggested that this polymorphism is a candidate factor for accelerated nephropathy in type 2 Diabetes.

\section{Acknowledgments}

The authors wish to express their gratitude to the dean of Airlangga University School of Medicine, Professor Dr. med. Mohammad Amin, Head of the Division of Nephrology, Internal Medicine 
Department, Airlangga School of Medicine, all staff, nurses, and patients at the Dialysis Unit of Dr. Soetomo Hospital, Surabaya, Indonesia, and the Chairman of the Indonesian Society of Nephrology (INaSN), Prof. Dr. Suhardjono, PhD. We also thank Dr. Mitsuo Tanimoto and Dr. Maki Murakoshi at the Division of Nephrology, Department of Internal Medicine, Juntendo University Faculty of Medicine for their support.

\section{References}

1) David G H, Maria CG : Oxidative stress and hypertension. Med Clin N Am, 2009 ; 93 : 621 635.

2) Gross SS, MS Wolin : Nitric oxide : pathophysiological mechanism. Annu Rev Physiol, 1995 ; 57 : 737 769.

3) Lee KH, Baek MY, Moon KY, et al : Nitric oxide as a messenger molecule for myoblast fusion. J Biol Chem, 1994 ; 269 : 14371 14374.

4) Zhihong Yang, Xiu-Fen Ming : Recent advances in understanding endothelial dysfunction in atherosclerosis. Clin Medicine \& Research, $2006 ; 1: 53 \sim 65$.

5) Bachmann S, Bosse HM, Mundel P : Topography of nitric oxide synthesis by localizing constitutive NO synthases in mammalian kidney. Am J Physiol, 1995 ; 268 : 885 898.

6) Kone BC, Schwobel J, Turner P, et al : Role of $\mathrm{NF}^{-}{ }_{\mathrm{K}} \mathrm{B}$ in the regulation inducible nitric oxide synthase in an MTAL cell line. Am J phsiol, $1995 ; 269:$ 718 729.

7) Woltz M, Schmetterer L, Ferber W, et al : Effect of nitric oxide synthase inhibition of renal hemodynamics in man : reversal by L-arginine. Am J Physiol, 1997 ; $272:$ 178 182.

8) Raij L, Baylis C : Glomerular actions of nitric oxide. Editorial review. Kidney Int, $1995 ; 48: 20 \sim 23$.

9) Kone $\mathrm{BC}$, Baylis $\mathrm{C}$ : Biosynthesis and homeostatic roles of nitric oxide in the normal kidney. Am J Physiol, 1997 ; 272 : 561 578

10) Baylis C, Harvey J, Engels $K$ : Acute nitricoxide blockade amplifies the renal vasoconstrictor actions of angiotensin II. J Am Soc Nephrol, 1994 ; 5 : 211 214.

11) Patzak A, Lai EY, Mrowka R, et al : AT1 receptors mediate angiotensin II-induced release of nitric oxide in afferent arterioles. Kidney Int, 2004 ; 66 : 1949 1958

12) Wesseling S, Ishola DA, Joles JA, et al : Resistance to oxidative stress by chronic infusion of angiotensin II in mouse kidney is not mediated by $\mathrm{AT}_{2}$ receptor. Am J Physiol Renal Physiol, 2005 ; 288 : 1191 1120.
13) Fellner SK, Arendshorst WJ : Angiotensin II, reactive oxygen species and $\mathrm{Ca}^{25}$ signaling in afferent arterioles. Am J Physiol Renal Physiol, 2005 ; Jun 7 [Epub ahead of print].

14) Liu R, Carretero OA, Ren $Y$, et al : Increased intracellular $\mathrm{pH}$ at the maculadensa activates nNOS during tubuloglomerular feedback. Kidney Int, 2005 ; 67 : 1837 1843.

15) Juncos R, Garvin JL : Superoxide enhances $\mathrm{Na}-\mathrm{K}-2 \mathrm{Cl}$ cotransporter activity in the thick ascending limb. Am J Physiol Renal Physiol, 2005 ; 288 : 982 987.

16) Herrera M, Garvin JL : A high-salt diet stimulates thick ascending limb eNOS expression by raising medullary osmolality and increasing release of endothelin-1.Am J Physiol Renal Physiol, 2005 ; 288 : 58 64.

17) Morishita T, Tsutsui M, Shimokawa H, et al : Nephrogenic diabetes insipidus in mice lacking all nitric oxide synthase isoforms. Proc Nat Acad Sci USA, 2005 ; 102 : 10616 10621.

18) Fuller TF, Freise CE, Feng S, et al : Ischemic preconditioning improves rat kidney graft function after severe ischemia/reperfusion injury. Transplant Proc, 2005 ; $37: 377 \sim 378$

19) Peresleni T, Noiri E, Bahou W F, et al : Antisense oligodeoxynucleotides to inducible NO synthase rescue epithelial cells from oxidative stress injury. Am J Physiol, 1996 ; 270 : 971 977.

20) Lieberthal $\mathrm{W}:$ Biology of acute renal failure : Therapeutic implications. Kidney Int, $1997 ; 52:$ 1102 1115.

21) Witko-Sarsat V, Gausson V, Nguyen AT, et al : AOPP induced activation of human neutrophil and monoocyte oxidation metabolism : a potential target for $\mathrm{N}$-acetylcystein treatment in dialysis patients. Kidney Int, 2003 ; $64: 82 \sim 91$.

22) Jo SK, Hu X, Yuen PST, et al : Delayed DMSO administration protects the kidney from mercuric chloride-induced injury. J Am Soc Nephrol, $2005 ; 15$ : 2648 2654.

23) Kurata H, Takaoka M, Kubo Y, et al : Protective effect of nitric oxide in ischemia/reperfusion-induced renal injury and endothelin-1 overproduction. Eur J Phamacol, $2005 ; \mathbf{5 1 7}: 232 \sim 239$

24) Yamasowa H, Shimizu S, Inoue T, et al : Endothelial nitric oxide contributes to the renal protective effects of ischemic preconditioning. J Pharmacol Exp Ther, 2005 ; 312 : 153 159.

25) Bonnardeaux A, Nadaud S, Charru A, et al : Lack of evidence for linkage of the endothelial cell nitric oxide synthase gene to essential hypertension. Circulation, 
$1995 ; 91: 96 \sim 102$.

26) Wang XL, Sim AS, Badenhop RF, et al : A smokingdependent risk of coronary artery disease associated with a polymorphism of the endothelial nitric oxide synthase gene. Nat Med, $1996 ; 2: 41 \sim 45$.

27) Miyahara K, Kawamoto T, Sase K, et al : Cloning and structural characterization of the human endothelial nitricoxide-synthase gene. Eur J Biochem, $1994 ; 223$ : $719 \sim 726$.

28) Hibi K, Ishigami T, Tamura K, et al : Endothelial nitric oxide synthase gene polymorphism and acute myocar- dial infarction. Hypertension, 1998 ; $32: 521 \sim 526$.

29) Thaha M, Pranawa, Yogiantoro M, et al : Association of endothelial nitric oxide synthase Glu298Asp polymorphism with end-stage renal disease. Clin Nephrol, 2008 ; $70: 144 \sim 154$.

30) Miyamoto Y, Saito Y, Kajiyama N, et al : Endothelial nitric oxide synthase gene is positively associated with essential hypertension. Hypertension, $1998 ; 32: 3 \sim 8$.

31) Noiri E, Satoh H, Taguchi J, et al : Association of eNOS Glu298Asp polymorphism with end-stage renal disease. Hypertension, $2002 ; 40: 535 \sim 540$.

\title{
Reactive Oxygen Species, Nitric Oxide and the Kidney
}

\author{
活性酸素種, 一酸化窒素と腎
}

モハマドタハ*1)3)

Mochammad THAHA

\author{
エミリア タヌセプトラ*2) \\ EMILIA S TANUSEPUTRA
}

抄録

末期腎障害 (ESKD) 患者では, 心血管疾患の発症が増加することが知られている。血管疾患 の発症・進展に酸化ストレスが注目されている. 酸化ストレスマーカーのなかでも一酸化窒素 (NO) は，L-アルギニンを基質として一酸化窒素合成酵素 (NOS) より生成される半減期の非常に 短いフリーラジカルであり, 強力な作用をもつ. 特に血管内皮においては, 内皮型一酸化窒素合成 酵素 (eNOS) からのNO産生が血管内皮障害の進展に深く関与していることが知られている。また, eNOSの遺伝子多型が高血圧や糖尿病の進展に関与しているとの報告もみられているが, eNOSの 多型とESKD との関係については十分に検討されていない.

一方，ESKD患者ではホモシスチン $(\mathrm{HCY})$ と非対称型ジメチルアルギニン (ADMA) が増加し ており，透析患者においてHCYは独立した心血管障害のリスクファクターであり, ADMAは心血 管イベントのリスクを $34 \%$ 増加させることが知られている. 最近, N-アセチルシステイン (NAC) はHCYやADMA を低下させることが報告されており，ESKD患者における心血管疾患発症の予防 因子の一つとして注目されている.

本稿では, インドネシアのESKD患者における eNOSの遺伝子多型（Glu298Asp）およびHCY と ADMAに関連したNACの役割に注目し，最近の知見をふまえて概説する. キーワード：酸化ストレス，一酸化窒素 (NO)，eNOS，末期腎障害 (ESKD) 